\title{
THE RELATIONSHIP BETWEEN ICONS AND EDUCATION IN A POSTMODERN SOCIETY: HOW TEENAGERS RELATE TO THE PRESENCE OF THE ICONS INSIDE SCHOOLS AND OTHER PUBLIC PLACES
}

\author{
Dorin OPRIŞ* \\ Monica OPRIŞ*
}

\begin{abstract}
The Relationship between Icons and Education in a Postmodern Society: How Teenagers Relate to the Presence of the Icons inside Schools and Other Public Places. After the fall of the Communist regime, one of the new political system's educational policies was the reinstatement of Religious Education among the subjects taught in the Romanian public schools. This process was followed by the admittance of icons inside schools. Due to the fact that numerous other researchers point out the icon represents a significant formative factor in Romania, our research is intended to highlight some differences in how the icon is perceived as a means of education inside and outside schools according to the students' age. The majority of the interviewed students who were in their early teens perceived icons as a way of worshiping God whereas a change was noted in the way in which the students who were in their late teens perceive it and who felt the need to interiorize faith more. Another aspect that has been tackled by this research concerns the formative value that icons have in non-religious publications. Because of the inefficiency of educational programme in schools and churches which should have underlined the educational value of the icon during the children's different
\end{abstract}

PhD, Assistant Professor, "1 Decembrie 1918" University, The Teacher Training Departament, Alba Iulia, Romania.

$\mathrm{PhD}$, Religious Education Teacher, "St. Simion Ştefan" Orthodox Theological Seminary, Alba Iulia, Romania 
stages of development, our research stresses the reality of the danger of the desecration of icons because of the extent to which they are ignored in personal spaces or even thrown away together with the publications in which they have been printed.

Keywords: icon, education, teenagers, schools, desecration

\section{Premises}

We know that the first icon was not made by human hands ${ }^{1}$. On every $16^{\text {th }}$ August, the Synaxarium tells us the miraculous story of a painting: the most prestigious painter in Edessa captured on canvas the image of God. At that time, the King, who had heard about the miracles done by Christ, was suffering from leprosy. The king believed that he would be healed by looking at the Saviour's image. Since the time during which that icon had been painted to the time of the icons painted by Saint Luke and to our days, thousands of Christians felt that these are not simple two-dimensional representations of the image of holy people, but that they are fundamental elements of the faith over which it is worth losing one's life ${ }^{2}$.

Hundreds of thousands of Christians died throughout history, defending the icons. The Persians sacrificed over 100,000 Georgian Christians at the beginning of the $13^{\text {th }}$ century. Plundering and pillaging churches, the Persians conquered Tbilisi. They took icons from people's houses and placed them on the bridge across the Kura River. During these attacks, over 100,000 Georgians felt prisoners. Their freedom was promised in exchange for their apostasy, materialized in their spitting onto icons and walking over them. Because the Christians refused to commit apostasy, they were put to death and thrown in the river. To this day, that bridge is called 'The River of the Martyrs'.

In Romania, irrespective of the fact that icons had been kept in obscurity during the Communist oppression of the $20^{\text {th }}$ century, they were always present inside Orthodox Christians' homes, whether they

1 Leonid USPENSKY, Teologia icoanei în Biserica Ortodoxă, Bucureşti, Fundaţia Anastasia, 2009, p. 39-42.

${ }^{2}$ Paul EVDOCHIMOV, Arta icoanei. O teologie a frumuseţii, Meridiane, 1993, p. 145146. 
were displayed or not. The change in the political system offered a chance for religious freedom. Thus the religious art schools have been reopened and there has been a constant growth in the interest manifested for the different types of icons - traditional Romanian icons as wel as other icon styles belonging to other Orthodox areas. Thus, the icon has re-entered the public spaces, including schools, and knowledge about icons and their worship have become part of the syllabus for Religious Education.

Through our research, we intend to analyse some aspects in connection to the manner in which pre-adolescents and adolescents relate to icons in their schools and other public spaces. The data collected from over 400 students in Alba County was analysed according to different variables, such as gender, class, level of education, family environment etc.

\section{Functions of the icons}

The veneration of the icons inside the Orthodox Church highlights their special place within the liturgical life, in accomplishing the religious education or in different missionary contexts. By rendering in images and symbols different aspects of the Holy Scripture and the life of the Church, the icon is both a window into the Absolute and window beyond the Absolute. It provides support for the believers who are on their way to attaining communion with God; the icon sheres God's unseen power through what it represents. By venerating icons, one venerates the Saint who is represented in it. Furthermore, the icon is a means of revitalizing, maintaining and strengthening the spiritual life. and the veneration of the icons exhorts one to do good deeds and to practice the Christian virtues. Hence, we have five important functions of the icons: catechetical, contemplative, charismatic, latreutic, and educational.

Through our research, we mean to identify which of the functions of the icon are valued by students and the differences that appear according to variables in age, gender, class, residency, education, involvement in the religious life, and family environment. We have formulated a representative statement for each of the functions: 


\begin{tabular}{|c|c|}
\hline Statements about icons & Function \\
\hline $\begin{array}{l}\text { a. When I saw an icon, I learned new things about the holy } \\
\text { man or the event depicted in it. }\end{array}$ & Catechetical \\
\hline $\begin{array}{l}\text { b. When I prayed in front of an icon, I felt a great power } \\
\text { sourcing from it. }\end{array}$ & Contemplative \\
\hline $\begin{array}{l}\text { c. When I saw an icon, I felt the need to follow the example } \\
\text { of the saints it represents. }\end{array}$ & Charismatic \\
\hline d. When I saw an icon, I felt the need to praise the Lord. & Latreutic \\
\hline $\begin{array}{l}\text { e. When I saw an icon, I remembered that man is called to go } \\
\text { to Heaven. }\end{array}$ & Educational \\
\hline
\end{tabular}

The students were asked to choose two of the statements included in the list that they considered to be most representative. The results are synthesised in Table 2, in which we have also included an analysis based on gender.

Distribution of respondents' answers regarding the

Table 2

functions of icons, based on the respondents' gender

\begin{tabular}{|c|c|c|c|}
\hline \multirow[t]{2}{*}{ Answers } & \multirow[b]{2}{*}{$\begin{array}{c}\text { Total } \\
\%\end{array}$} & \multicolumn{2}{|c|}{ Gender } \\
\hline & & $\begin{array}{c}\text { Boys } \\
\%\end{array}$ & $\begin{array}{c}\text { Girls } \\
\%\end{array}$ \\
\hline Catechetic & 45,5 & 46,53 & 44,44 \\
\hline Charismatic & 46,5 & 39,60 & 53,53 \\
\hline educational-religious & 20 & 20,79 & 19,19 \\
\hline Latreutic & 43 & 42,57 & 43,43 \\
\hline Contemplative & 38 & 45,7 & 30,3 \\
\hline
\end{tabular}

The data presented in Table 2 shows a balanced distribution of the answers given in regard to three of the functions of the icons: the catechetic, the charismatic one and that through which the icon represents a mean of worshiping God. The difference between the boys' and the girls' answers in these categories is smaller than 5\%. The contemplative function was preferred by $38 \%$ of the students while the educationalreligious one by $20 \%$, thus making the amplitude of the results reach 26.5 percentage points.

The data illustrates some aspects concerning the students' spiritual life and the way in which the icon is valued in the school environment. 
Beginning from the earliest stages of their development, children with an Orthodox background are taught to pray to the person or the persons who are represented in the icons, which emphasizes awareness of the fact that prayers are more powerful if done as such. Furthermore, using the icon as a means of education helps us understand the higher percentage of students who chose the statement regarding the part the icons play in the accumulation of knowledge from a religious perspective.

Shaping a man's conscience in connection to his eternal destiny and his appropriation of the model offered by the saints as a result of contemplating the icons in which these saints are represented are things that have a lesser values in the life of Christians and in the school environment ${ }^{3}$.

If we take into analysis these results factoring in the students' gender, we notice differences of more than 10 percentage points in the case of the charismatic function (a difference which is in favour of the girls by $13.93 \%$ ) and of the contemplative one function (a difference which is in favour of the boys by 15.4\%). The Pprayer uttered in front of an icon brings strength, and because this is perceived at a deeper level by girls, points to their need to overcome their disposition and even some fears, which are specific to their age. When contemplating an icon, boys meditate about man's eternal destiny

If we analyse the data based on the age factor, we notice a series of

The distribution of the students' answers regarding the

Table 3

functions of the icons based on the respondents' age differences, as shown in Table 3:

\begin{tabular}{|l|c|c|c|c|c|c|}
\hline \multirow{2}{*}{\multicolumn{1}{|c|}{ Function }} & \multicolumn{7}{c|}{ Age } \\
\cline { 2 - 8 } & $\mathbf{1 1 3}$ & $\mathbf{1 1 4}$ & $\mathbf{1 1 5}$ & $\mathbf{1 1 6}$ & $\mathbf{1 1 7}$ & $\mathbf{1 1 8}$ \\
\hline Catechetic & 21,9 & 18,6 & 16,48 & 9,89 & 8,8 & 8,8 \\
\hline charismatic & 10,7 & 8,6 & 18,3 & 15,1 & 21,5 & 12,9 \\
\hline religious-educational & 45 & 12,9 & 15 & 2,5 & 12,5 & 7,5 \\
\hline worshiping God & 19,7 & 16,2 & 10,5 & 9,3 & 13,9 & 10,4 \\
\hline contemplative & 17,1 & 13,2 & 19,7 & 10,5 & 17,1 & 11,8 \\
\hline
\end{tabular}

${ }^{3}$ Dumitru VANCA, Icoană şi Cateheză, Alba Iulia, Reîntregirea, 2005, p. 192. 
The number of people who see the icon as "a Picture Bible" decreases between the age of 13 and that of 18 under the influence of the fact that, in high school, Religious Education is taught through methods that use very little of the intuitive material's formative potential.

The data indicates larger values for three up to four of the icon's functions for respondents aged 15 and 17. A possible explanation of this phenomenon might reside in the fact that at the beginning of grade 10 and towards the end of grade 11 there are topics connected to the icon in the official Religious Education syllabus, such as: worshiping the icons, elements of iconography and the significance of icon settings inside the church building.

The data gathered highlight the importance of the topics which give value to the icons and the part this plays in a Christian's life. In the case of the students who were in their early teens, we noticed that the highest values recorded were for the icon's religious-educational function, followed by the catechetical and God-worshiping ones. At the same time, the students who were in their late teens have come a more balanced approach to icons, because they internalize certain aspects pertaining to faith.

\section{How students relate to the icon in their classroom}

The presence of religious symbols in public places represents a topic that re-emerges with a certain frequency in media debates, in spite of the rulings of some international courts which favoured such symbols. For example, there was a CEDO decision on $18^{\text {th }}$ March 2011, in which the majority of voters agreed that the presence of crosses inside classrooms is not indoctrination of children and does not violate the parents' rights of ensuring for their children an education and an educational system according to their own philosophical and religious concepts ${ }^{4}$.

In Romania, between the two World Wars, icons were symbols of faith and their formative-educational part was recognized and evidenced by the Ministry: "there will be icons on the wall of the schools to help in the

4 Teofil TIA, „Preocupare pastorală prioritară şi constantă a Bisericii Catolice din Italia: predarea religiei în învăţământul public de stat”, in Dorin OPRIŞ, Monica OpRIŞ, Religia şi şcoala. Cercetări pedagogice, studii, analize, Bucureşti, Editura Didactică şi Pedagogică, R.A., 2011, p. 112-113. 
enrooting and shaping of the moral character". 5 Attacks against Religious Education were followed by attacks against the presence of the icons inside classrooms. Even if students take for granted the presence of the icons inside their classrooms just because in most cases icons were already present in those rooms before the students' arrival, the importance of icons in the spaces in which education is provided is reflected in the prayers that the students themselves utter on various occasions while gazing at the icons.

The purpose of our questionnaire was to point out what the icons present in the classrooms are meaning for the students. In this respect we have opted for an open item, which provides a larger range of answers. From the total of interviewees, $86.5 \%$ formulated a positive answer, $9.5 \%$ merely consider the icon a classroom object while the remainder $4 \%$ did not provide an answer.

Based on the students' age, the analysis of their answers to the question "What does the icon in your classroom represent to you?" shows both similarities and differences. Despite finding similar or even identical answers, the frequency of these answers is different for students in their early teens as compared to students who are approaching high school graduation.

At the beginning of adolescence, students stress aspects connected to the parts icons play for them personally and also in the life of their class. The icon has been mostly viewed as a means of being closer to God: "a holy object which helps us be closer to God", "a step closer to God", "a meeting with God after a prayer", "a way to God" or "a gateway to God". These are followed by answers regarding the part played by the icon in the life of the class thanks to its unifying power: "the kindness that unites our class", "the source of our class's strength", "the peace that unifies us", "the kindness and the love that unites us", and "the protector of our class". The part icons play in special situations, such as students' assessments, is also mentioned with a high frequency: "an object which helps me in need" and "it makes me be more confident and it provides me help during tests". The answers also indicated the importance of icons as a protective presence of God in man's life, of these being a physical representation of God's grace: "the most holy place in our classroom", "the symbol of God's care for us", "God's presence

${ }^{5}$ Our translation. Pantilimon POPOVICI, “1918-1948: Trei decenii de educaţie religioasă. Modele de bun practici instituţionale şi moral-creştine în şcoala românească”, în Dorin OPRIŞ, Monica OPRIŞ, Religia şi şcoala ..., p. 273. 
among us" and "a trace of holiness". There were some answers that identified the icon as "a source of personal strength", "a source of personal tranquility", "personal protection and safety" or "foundation of spiritual tranquility and peace". The icon as a symbol of allegiance to the Orthodox faith is also underlined in the students' answers: "sign of our faith in God", "proof of the fact that we are faithful children", and "a remembrance that we are Christian".

It is important to notice that the catechetical function of the icon is most represented in the answers provided by the preadolescents and yet only one student stated the role the icon plays as "a picture lesson".

The adolescents gave more answers about the icon being "a sign of protection", "a blessing, a means of surpassing all obstacles", "protection, which gives me beneficial inner strength", "blessing, protection, and trust", "a helper throughout difficult times" and about the icon as a consecrated object with the help of which one can be in communion with God with greater ease: "it is a holy object that helps me speak to God", "it is the connection between us and God", "it is an object that reminds me to pray", "it is the connection with God", "it is a gateway to the Kingdom of God", "it is a place for meditation in which you can communicate better with God", "it is a sign that reminds us to pray", "it is a means of communication with the persons it represents", "it is a consecrated object" and "it is a window to Heaven". There is a high incidence of the answers referring to the personal relationship the student has with God by means of the icon: "icons are a joy because when I see them, I feel better", "the icon is a presence that reminds me to set aside any evil thoughts and pray", "it is a model of holiness", and "I believe that an icon can perform miracles". The part the icon plays in the life of the class is less frequently mentioned in the answers of the students: "it is the protection of the class", and "it is the most important thing in our classroom". There is lower incidence in the students' answers regarding the presence of God in man's life: "the icon is witness to God's omnipresence through His protection and help", "the icon is a presence of God among us", "it is God's gaze on us", "it is an instance of God's presence among us" and "it represents the presence of God and of the saints". All these answers correspond to the data collected from the answers to the previous item, regarding the functions of the icons, especially those connected to the charismatic and contemplative functions. There have also been answers with a negative connotation, such as those that claim that the icon is merely a 
painting.

Another aspect of the questionnaire regarded the content of the icon. Students were asked about whom should be represented in the icon. From the $69.5 \%$ of the students who had an opinion on this matter, $39.4 \%$ opted for an icon of our Lord Jesus Christ, $36.5 \%$ for one of our Holy Theotokos holding Baby Jesus while the difference to $100 \%$ is made up with answers such as: the icon of the Saviour and of Virgin Mary (15.5\%) or the icon of a saint $(8.6 \%)$, especially that of Saint Nicholas, protector of children. An analysis of these answers based on gender distribution point to the fact that most girls preferred an icon of our Holy Theotokos with Baby Jesus while both male and female $7^{\text {th }}$ to $9^{\text {th }}$ grade students opted for Saint Nicholas' icon.

From the total number of responders, $19.3 \%$ did not mention any specific preference about the choice of a certain icon and $9.2 \%$ of the answers were non-answers. There have also been a few students (2\%) who said they would like not to have icons in the classroom. One of the students even said, "I do not have a preference at all, but who am I to cut all hope from men?"

The presence of icons in the classrooms can trigger some specific religious behaviour in the students, which is manifested in occasions besides prayers led by the Religious Educationteacher. Through our research we intend to find out if the students ask for the help of the person represented in their class's icon before an assessment.

The research data is synthetised in Table 3.We have also included a distribution of the answers based on gender. We would like to mention the fact that the students had the possibility to choose more than one answer.

The distribution of the answers regarding the relationship

Table 4 between prayers and icons

\begin{tabular}{|l|l|l|l|}
\hline \multirow{2}{*}{ Answers } & \multirow{2}{*}{$\begin{array}{c}\text { Total } \\
\text { Statements }\end{array}$} & $\begin{array}{c}\text { Goys } \\
\text { \% }\end{array}$ & $\begin{array}{c}\text { Girls } \\
\text { \% }\end{array}$ \\
\hline I pray gazing at the icon in the classroom. & 73,4 & 46,7 & 53,3 \\
\hline I pray looking at the icons I carry with me. & 14,4 & 36,8 & 63,2 \\
\hline I pray without looking at any icon. & 12,5 & 58,1 & 41,9 \\
\hline I don't pray. & 5,5 & 78,3 & 21,7 \\
\hline
\end{tabular}

The data included in Table 4 highlight the importance of the classroom icon in the student's life, regardless of gender. There are 
differences in the personal significance of icons for the student who carries them on himself/herself while praying. Moreover, there are students who utter a silent prayer without connecting it to any particular icon and students who do not pray at all before assessments. The latter do this for various reasons, such as: "I have studied", "it is pointless because I haven't studied", "I don't believe prayers can help me", "praying in not a habit of mine", "I don't believe in god", etc.

\section{The students' attitude regarding icons present in various non- religious publications}

The religious fervour that was felt in post-1989 Romania brought a radical change in the publishing world as well. There has been an increment in the number of religious publications while the non-religious ones dedicate sections to religious issues which are very often illustrated with icons. The icons can be found with greater ease and this is noticeable in all places: in people's homes, in schools and other public buildings, inside the cover of students' cards, in their pencil cases, on the cover of their textbooks, on the front page of their research paper, graduation albums and pictures, in restaurants, hotel rooms, in various publicity leaflets of high profile chain stores, on stamps, cards, etc.

The question we asked ourselves for this research was: "Is this 'inflation' of icons continued with a lesson about how they should be worshipped according to the value they have for Orthodox spirituality?"

In this respect, we have formulated two items to help us find out whether the presence of icons in the pages of non-religious publications is beneficial or not and what is the students' behaviour when they have to decide what to do with an icon in a non-religious publication (magazines, newspapers, calendars, cards, stamps, etc.) when the product in which the icon was used is no longer useful.

The data collected during the research shows that $87.5 \%$ of students consider the presence of icons inside non-religious publications is beneficial and the main reason behind their statements is the opportunity of offering religious information through other means: "people can find out more about the Christian faith", and "these icons inform us and remind us about the spiritual life". Secondarily, the students provided motivations about the purpose icons have in reminding people 
about the spiritual life and about their missionary purpose: "the icon is a way of reminding people about the God that helps the forgetful ones", and "we must promote our faith through the most diverse means".

The $11 \%$ who claim that it is not advisable to include icons in the pages of non-religious publications argue that "religious things should not be mixed with non-religious ones", and that "people might put in the trash the icons together with the newspaper or magazine". The low percentage of students who supported these statements did not allow us to analyse their replies according to different variables.

Our preoccupation with the manner in which students worship icons has been materialized in a leading item through which we asked the students to mention a few example of what they do with the icons they find inside different non-religious publications. Table 5 presents the frequency of the students' choices between the options we set for them and the analysis of the data according to the gender of the respondents..

The students' attitude in confront to the icons printed in

Table 5 non-religious publications

\begin{tabular}{|l|c|c|c|}
\hline \multirow{2}{*}{ Answers } & \multirow{2}{*}{ G oStatements } & \multicolumn{2}{|r|}{ Gender } \\
\cline { 4 - 5 } & Total & Boys & Girls \\
\% & \% \\
\hline $\begin{array}{l}\text { a. I ignor the fact these publications include icons and } \\
\text { I throw them in the trash can. }\end{array}$ & 45 & 54,45 & 35,35 \\
\hline b. I cut out the icons and I keep them. & 41,5 & 34,65 & 48,48 \\
\hline $\begin{array}{l}\text { c. I cut out the icons and I put them in a special place } \\
\text { (in a flowing water, at the root of flowers/trees) }\end{array}$ & 2,5 & 1,98 & 3,33 \\
\hline d. I do things differently. How? & 10,5 & 7,92 & 5,55 \\
\hline
\end{tabular}

The data from Table 5 shows that abouthalf (45\%) of the students ignore the presence of icons in non-religious publications and throw these away altogether. A gender-based analysis of the data points to the fact that boys are more prone to this kind of behaviour than girls due to the almost $20 \%$ that separates the two categories.

The analysis of the data according how often students take Communion highlights the connection between students' religious life and their behaviour towards icons, as illustrated in Table 6 . 
The attitude students have towards the icons in the non-

Table 6 religious publications compared to the frequency with they take Communion

\begin{tabular}{|l|l|l|l|}
\hline \multicolumn{1}{|c|}{ Communion frequency } & $\begin{array}{l}\text { every } \\
\text { month }\end{array}$ & $\begin{array}{l}\text { fasting } \\
\text { periods }\end{array}$ & $\begin{array}{l}\text { Once a } \\
\text { year }\end{array}$ \\
\hline $\begin{array}{l}\text { a. I ignor the fact these publications include } \\
\text { icons and I throw them in the trash can. }\end{array}$ & 27,27 & 43,75 & 59,25 \\
\hline b. I cut out the icons and I keep them. & 45,45 & 42,85 & 37,93 \\
\hline d. I do things differently. How? & 18,18 & 12,5 & 0 \\
\hline
\end{tabular}

Students who take Communion more frequently are also more careful regarding other aspects of religious life, including how icons are worshipped. Those who take Communion once a year, at best, ignore icons and dispose of them with greater ease (59.25\%).

The majority of answers which gave other solutions about the manner in which people relate to the icons in non-religious publications refer to positive aspects of icon worshipping: "I keep the magazine without cutting out the icons", "I keep the calendars year after year", "my mum deals with these aspects", "I burn the icons and I place the ashes in a pristine location" etc.

The data collected through the research shows there is a need to reconsider the religious education done by the school and the church regarding the worshiping of the icons. Questions, such as: How does one worship an icon in church and at home? How does one treat a book, a magazine, a calendar, a newspaper, etc. which includes an icon? How does one say a prayer in front of an icon? Answers should be provided according to the individual's biological age and spiritual development..

\section{Instead of a conclusion}

Almost ten years ago, we went on a pilgrimage in Italy, organized by the Archbishopric of Alba Iulia. There was a crowd inside the Vatican Museum, in which Christians and non-Christians mingled continuously from sunrise to sundown wishing to admire true artistic values. At one point during our visit, the security of the museum became alert. An elder from our group knelt down and prostrated himself at the sight of the first icon. From the moment onwards, he was closely followed by the guards 
until we reached the last chamber of the museum, even if the guards had been ensured that there was no danger and that the man was an authentically religious man. Although seeing and knowing he is being watched as one would watch a wrong-doer, our fellow pilgrim did not give up his veneration for the icons until he had completed his ritual for all the icons exhibited in the museum.

$\mathrm{He}$, the icon venerator, was considered dangerous and maybe even insane while all the others were perceived as being normal!

\section{References}

1. Evdochimov, Paul, Arta icoanei. O teologie a frumuseţii, Meridiane, 1993, p. 145-146.

2. OPRIŞ, Dorin, Dimensiuni creştine ale pedagogiei moderne, Bucureşti, Didactică şi Pedagogică, 2012.

3. OPRIŞ, Dorin, "Influences of the adolescent crisis in the parent-child relation", in Iulian Boldea (ed.), Globalization and intercultural dialogue: multidisciplinary perspectives, Proceedings of GIDNI 1, Târgu Mureş, Arhipelag XXI Press, 1/2014.

4. OPRIŞ, Dorin, OpRIŞ, Monica, "Teenagers'models of understanding suffering", in: European Journal of Science and Theology, 8:2/2012.

5. OPRIŞ, Dorin / OPRIŞ, Monica, Valori, modele şi aşteptări ale liceenilor din judeţul Alba, Cluj-Napoca, Eikon, 2015.

6. OPRIŞ, Monica, "Adolescenţii de azi şi valorile religios-morale. Rolul sfântului ocrotitor al clasei în dezvoltarea spirituală a liceenilor", în Adrian Lemeni (coord.), Repere ale educaţiei creştine în teologia Sfântului Ioan Gură de Aur, actualizate în relaţia Biserică-FamilieŞcoală din contextul contemporan, Bucureşti, Basilica, 2015.

7. USPENSKY, Leonid, Teologia icoanei în Biserica Ortodoxă, Bucureşti, Fundaţia Anastasia, 2009, p. 39-42.

8. VANCA, Dumitru, Icoană şi Cateheză, Alba Iulia, Reîntregirea, 2005, p. 192. 